\title{
Hospital based palliative care approach to HIV/AIDnt; a Nigeria experience
}

\author{
Folaju Olusegun Oyebola \\ From $16^{\text {th }}$ International Symposium on HIV and Emerging Infectious Diseases \\ Marseille, France. 24-26 March 2010
}

\section{Background}

This study evaluates the role of Hospital Based Palliative Care services in scaling up HIV/AIDS management and reduction of social and self discrimination in HIV/AIDs patients.

\section{Methods}

The hospital medical advisory approved a Multidisciplinary team consultation and the inauguration of the HIV/AIDS clinic under the chairmanship of a trained palliative care physician. The clients consult any of the hospital specialist team depending on the needs and these include peadiatrician, community physician, pharmacist, social workers, nutritionist, surgeon, internal physician, spiritual leader, obstetrics and gynaecologists.

\section{Results}

The clients number increased from six (6) to seventyfive (75) within 3 months. More than two-thousands patients are currently enrolled with $72 \%$ on free HAART. A significant success had been recorded in the Prevention of Mother to Child Transmission, drug adherence, home based care and support group.

\section{Discussion}

The multidisciplinary team care approach facilitated the upsurge in the number of new cases and an improved confidence in the health care providers. The previous culture of discriminating against the patients by the hospital staff is now replaced by friendship and improved quality of care.

Published: 11 May 2010

Correspondence: fooyebola@yahoo.com

pain And Palliative Medicine Department. Federal Medical Centre Idi-Aba. P. M.B 3031, Sapon P.O., Abeokuta, Nigeria

○ 2010 Oyebola; licensee BioMed Central Ltd.
doi:10.1186/1742-4690-7-S1-P94

Cite this article as: Oyebola: Hospital based palliative care approach to HIV/AIDnt; a Nigeria experience. Retrovirology 2010 7(Suppl 1):P94.
Submit your next manuscript to BioMed Central and take full advantage of:

- Convenient online submission

- Thorough peer review

- No space constraints or color figure charges

- Immediate publication on acceptance

- Inclusion in PubMled, CAS, Scopus and Google Scholar

- Research which is freely available for redistribution

Submit your manuscript at www.biomedcentral.com/submit 